\title{
LEAD COMMUNITY GROUPS IN NSW
}

$S_{\text {in }}^{\text {in }}$ nce the 1960 s health, environment, advocacy and community groups have campaigned on lead issues in Australia (Table 1). Some groups have dealt with lead contamination as part of broader health or environmental issues, including:

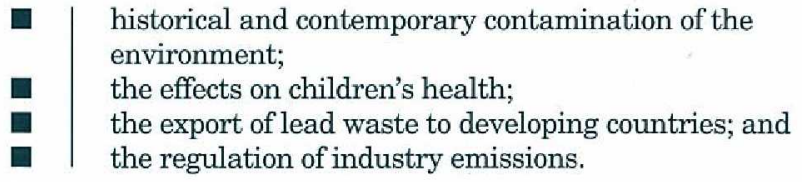
Several groups have focused on specific locations, concentrating their attention on developments or industries such as waste disposal facilities or chemical factories.

Four NSW community groups focus specifically on lead issues:

\section{THE LEAD EDUCATION AND ABATEMENT DESIGN (LEAD) GROUP}

The Lead Education and Abatement Design (LEAD) Group, based in Sydney, was established in 1991 by a group of parents whose children's health had been affected by lead. The group's goal is "to eliminate childhood lead poisoning by 2002 and protect the environment from lead". The LEAD Group's two main areas of activity are community education and advocacy on lead issues. The NSW Government currently funds the Group to run the Lead Advisory Service (NSW), which provides a range of free services to parents and the community, including:

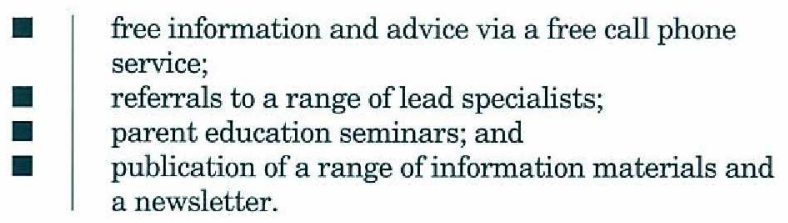

The free call phone of the Lead Advisory Service (NSW) (1800 626086 ) receives more than 300 calls a month from concerned parents.

\section{NORTHERN LAKES ENVIRONMENTAL ACTION DEFENCE (NO LEAD)}

Northern Lakes Environmental Action Defence (NO LEAD) was formed in 1990, following residents' concerns of environmental contamination from a lead-zinc smelter at North Lake Macquarie. The smelter has been in operation since last century. The group focuses on child health and the environment and has been campaigning for the reduction of emissions from the smelter and the remediation of North Lake Macquarie.

\section{MARAYONG ACTION GROUP}

The Marayong Action Group was formed in 1993 by residents living near a proposed lead-acid battery factory plant in the western Sydney suburb of Marayong. As a result of the high level of community concern, conditions were attached to the development proposal to deal with lead contamination issues. The group is still represented on the community forum set up as part of the development conditions.

\section{ILLAWARRA RESIDENTS AGAINST TOXIC ENVIRONMENTS (IRATE)}

The IRATE group was formed by residents concerned about the health and environment effects of current emissions and historical contamination from heavy industry in the Port Kembla area, south of Wollongong.

The organisation participates in a range of committees that consider environmental issues associated with lead and other pollutants. It is also involved in developing community awareness about the effects of lead.

Further information is available from Elizabeth O'Brien, 97160014.

\section{TABLE 1}

ORGANISATIONS INVOLVED WITH LEAD ISSUES

\begin{tabular}{|c|c|}
\hline Group & Issue \\
\hline $\begin{array}{l}\text { ADI Residents Action } \\
\text { Group }\end{array}$ & $\begin{array}{l}\text { Pollution at Australian } \\
\text { Defence Industry sites }\end{array}$ \\
\hline Ardeer Residents Group & Lead-acid battery factory \\
\hline $\begin{array}{l}\text { Australian Chemical } \\
\text { Trauma Alliance }\end{array}$ & $\begin{array}{l}\text { Toxic chemicals and } \\
\text { contamination }\end{array}$ \\
\hline $\begin{array}{l}\text { Australian Conservation } \\
\text { Foundation }\end{array}$ & Environment \\
\hline $\begin{array}{l}\text { Broken Hill Residents } \\
\text { Action Group }\end{array}$ & Lead issues in Broken Hill \\
\hline Consumers Health Forum & Consumer advocacy \\
\hline Friends of the Earth & Environment \\
\hline Greenpeace & Environment \\
\hline $\begin{array}{l}\text { Illawarra Residents Against } \\
\text { Toxic Environments (IRATE) }\end{array}$ & $\begin{array}{l}\text { Heavy industry in } \\
\text { Port Kembla }\end{array}$ \\
\hline $\begin{array}{l}\text { Inner Sydney Regional } \\
\text { Council for Social } \\
\text { Development }\end{array}$ & $\begin{array}{l}\text { Leaded petrol and urban } \\
\text { environment }\end{array}$ \\
\hline $\begin{array}{l}\text { Inner City Residents } \\
\text { Assisting their Environment }\end{array}$ & Waterloo incinerator \\
\hline $\begin{array}{l}\text { Lead Education and } \\
\text { Abatement Design (LEAD) } \\
\text { Group }\end{array}$ & $\begin{array}{l}\text { Community education and } \\
\text { advocacy }\end{array}$ \\
\hline Marayong Action Group & Lead-acid battery factory \\
\hline National Toxics Network & Chemicals \\
\hline $\begin{array}{l}\text { Northern Lakes } \\
\text { Environmental Action } \\
\text { Defence (NO LEAD) }\end{array}$ & $\begin{array}{l}\text { Lead-zinc smelter at North } \\
\text { Lake Macquarie }\end{array}$ \\
\hline $\begin{array}{l}\text { Public Interest Advocacy } \\
\text { Centre }\end{array}$ & $\begin{array}{l}\text { Public interest and advocacy } \\
\text { issues }\end{array}$ \\
\hline Total Environment Centre & Environment \\
\hline
\end{tabular}

